\title{
Big Bang - can confidence be restored in time?
}

\author{
by Hiroshi Goto
}

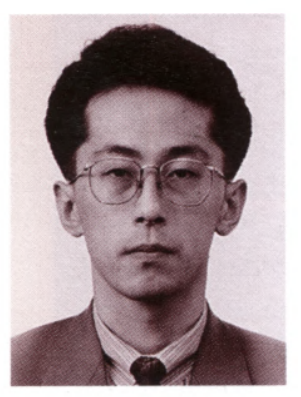

In the light of Professor Dalhuisen's comments in the preceding article, Hiroshi Goto gives his view of the reasons behind the current economic crisis in Asia. The author also details his vision of the likely future course of events in this region.

$\mathrm{D}$ uring the 'economic boom' of the 1980s, Japan was proud of the fact that its economic system had reached 'international standards' - unaware that the bubble had been inflating to bursting point. The position taken by commentators now is obviously different. As far as the banking system is concerned, this has come about via a series of collapses of banks and securities' houses, coupled with scandals uncovered in the process. While no-one seems to have linked it to the Asian economic crises, a closer look at what is happening inside Japan's banking system, especially in terms of its regulatory structure, might help identify the root of the problem in this Tiger economy.

It was a traditional 'national game' for Japanese business entities to 'put a lid on something pungent'; in other words, to hide any corporate scandal from the public. The root of the problem was sokaiya, or corporate racketeers, to whom companies made jllegal payments, in return for their promise not to disclose such scandals in meetings. This particular type of problem - that of corporate morale - is why the media, lawyers and business people are looking at 'corporate governance' problems differently from their counterparts in the AngloAmerican business field.

Currently, however, the problem is of a different type integrity in banking supervision and accountability in the accounting system. This concern has been further fuelled by the politicians dealing with these problems; and also by the bail-out of the entire Japanese economy due to the long-term recession.

\section{BANKING SUPERVISION - JAPANESE STYLE?}

As Professor Dalhuisen points out, the Japanese have tended to take temporary and patchy measures to solve problems: to rectify only that which is clearly identifiable and 'pretend that all others do not exist'. Despite public expectations of success with the Big Bang programme, it became clear that the Ministry itself, although the originator of the programme, was the very party which could do nothing but confirm the above observation, as the scandals were scrutinised one after another.

The following two cases clearly show what is now defined as 'systemic corruption' at the heart of what was once thought to be the driving force behind Japan's position as the world's number one economy. All those watching the Japanese economy must have realised that the key to success was the Ministry of Finance's 'convoy strategy', at the end of the Second World War, whereby it would never allow any banking or securities firm to collapse. made the most of its uncodified regulatory power to revive these to doubt that the best way to maintain economic confidence in Japan was to keep firms under supervision afloat; but the problems derived out of the scandals seem to have proved it wrong.

\section{The 'Objective' Approach}

One example emerged during the course of the liquidation of Yamaichi Securities. When share prices in the Tokyo Stock Exchange began to fall from 1990 onwards, Yamaichi was under threat of legal action by one client over losses incurred as a result, it was alleged, of 'bad management' of clients' funds in a discretionary account. The troubleshooting device which enabled these losses to 'disappear' from the balance sheets of either Yamaichi or its clients was tobashi, or 'transfer' of the losses to other companies having a different financial year. This enabled these losses never to appear or be recognised on the balance sheets of any of those involved at the end of the relevant financial year.

While Yamaichi had been successful in hiding the losses from the public, it was finally uncovered during the process of due diligence after its collapse. But this discovery was accompanied by another eye-opening allegation; a Yamaichi director confessed that tobashi was recommended by a Finance Ministry official!

\section{The 'Subjective' Approach}

Although the matter is still under investigation in the Yamaichi case, it is not the first of its kind. The fraudster involved in the Daiwa Bank scandal, in New York in 1995, wrote in his book The Confession, that Finance Ministry officials tried to conceal the huge losses he made from the US Federal Reserve Bank.

Another scandal - a more serious one - followed immediately after that: two inspectors from the Banking Bureau of the Ministry were arrested, having allegedly received bribes from those banks which were subject to their supervision. Those who knew how bank inspections were conducted (and here I speak from personal knowledge) must have been surprised at the arrests and confused as to why the prosecutors blew the whistle on something they had not previously been concerned about.

Every major Japanese bank is said to have middle managerial staff in charge of liaising with Finance Ministry officials for information. The information includes details of the expected Whenever any firm was under threat of insolvency, the Ministry firms, at the expense of other, healthier companies. It had no reason 
date of the visit by inspectors, which is supposed to be kept strictly secret. Staff are expected to obtain this information by offering a number of 'entertainment options' such as games of golf, package holidays overseas and, in an extreme case, dinners in a Japanese hot-pot restaurant where waitresses wear no underwear! In so doing, the banks successfully hid nonperforming debts from the inspectors. This was the 'trick', as one newspaper editor wrote, behind the most 'efficient' conduct of the inspections, albeit with a relatively small number of inspectors. As the investigation showed, one bank was alleged to have hidden the source of funds for illegal payments to a corporate racketeer from the inspectors.

\section{JAPANESE ACCOUNTING SYSTEM v THE INTERNATIONAL STANDARD}

What the Japanese banking system problem shares with the Asian financial crisis is the credit squeeze or lack of any sources from which to generate funds. Although the Tiger economies themselves partly contributed to this phenomenon, in Japan the main cause is, rather, a domestic one: the need for extra funds to write off the non-performing debts which accumulated during the 1980s economic boom. Other causes include the subsequent recession (including, perhaps, some part of the non-performing debts collected from their Asian clients) and their counter measures against the 'Japan premiums' added to the borrowings from their funding source after several major Japanese companies became insolvent late last year.

People have described the Japanese economy in the past by saying that 'once America sneezes, Japan will suffer from flu'. By the same token, the fatal collapse of Japanese banks would undoubtedly result in the death of the entire Japanese economy. The chief concern for banks was the increase in hidden or unrealised losses in shares that form a major part of their assets. As a result, the government allowed companies, including banks and insurance companies, as a part of a series of stimulant packages for its economy, to assess the value of stocks subject to their assets at the price at which they were acquired, rather than at the prevailing market price. The expectation was that they could artificially inflate the value of their assets and thus relax their credit squeeze against their clients. There has been, however, a mixed reaction from those who were allowed to do so. This is because the measure goes against the 'global standard' trend, which is one of the goals to be achieved in the Big Bang programme. The good news was that many banks and insurance companies were, at least initially, quite reluctant to take advantage of it: many became aware that the fact that the banks' choice of such an option could backfire, if the market construed it as a clear indication that the banks were on the verge of collapse.

\section{RELEVANCE TO THE CURRENT CRISES}

It is clear from directories of Japanese public companies that the top five shareholders in most major banks are life insurance companies. Until now, it would not have occurred to these public companies to rail against the banks as shareholders, as both the Japanese economy and the banks' financial results were prospering. The party - perhaps the only party - at the centre of corporate governance for these banks was and still is, to some extent, the Ministry of Finance. The Ministry had enjoyed absolute power through an unwritten code called 'administrative guidance'. This 'guidance' is given by officials in the Ministry and, in fact, has the force of law. To the surprise of western lawyers, no lawyer could attend meetings between Ministry officials and the bankers until recently, because every single word of that 'guideline' had 'the force of law' and there was absolutely no room for any other interpretation. Given what the scandals revealed, a question arises as to whether such governance structure was accountable or not.

While the economy prospered, nobody was concerned about this lack of transparency or accountability in corporate governance as regards the banks - in turn at the centre of governance for other Japanese businesses - through equity ownership or debt facility extension. Now the economy itself is in a downturn, and such governance structure is losing its balance of power.

As time goes by the Ministry of Finance is losing its regulatory power over these banks as well as its face to the public. Thanks to the investigators' enthusiasm, however, banks are under pressure to change their management structures and develop strategies to conform to the western standard. While that should be seen as a good thing, it is regrettable this change did not take place much earlier: the author suspects that the economic boom seen in the South East Asian region in the early 1990s had, given the resultant windfall for Japanese economy, made Japanese companies ignorant of their own problems, despite the emergence of the recession in the domestic economy at the time, and therefore made them reluctant to take appropriate action in time. Another problem which should be taken into account is that the pressure to which banks are subject does not seem to have reached other sectors, sectors that actually take the risks on major parts of non-performing debts in Asian countries by means of guaranteeing them to banks.

Up to the end of this financial year (March 1998), most risktaking companies have benefited from the lack of effective insolvency provisions in these countries, as almost none of these technically insolvent debtors could so declare. Because of this, it went against the trend towards more transparency in the sense that Japanese creditors take the old-fashioned attitude and decide not to recognise these debts as bad ones. Given that Japanese 'banks' are estimated to have contributed to more than half the off-shore borrowing by Indonesian business interests as well as Thai, there has to be some doubt as to whether the financial statements, disclosed in June 1997 at annual general meetings, are transparent enough.

From April 1998 onwards, slight changes in such attitudes can be expected: apart from the enactment of the new bankruptcy law in Thailand, by which Japanese companies should be forced to recognise bad debts, these Japanese companies will surely face derivative pressure from the banks through pressure from outside. As the Big Bang programme's measures are implemented one by one, it is reasonably foreseeable that Japanese banks would prefer to adopt westernised criteria of risk analysis to companies, when extending credit facilities to them. Furthermore, these companies will have to face further pressure of a similar type from different groups such as foreign institutional shareholders, the Californian Public Employers' Retrirement System and new equity market participants such as Merrill Lynch. A real soft landing for the Japanese economy, and indeed its success, depends largely on the management of these Japanese companies and whether they correctly understand the pressure to turn their companies in the right direction.

Hiroshi Goto

Legal Department, Nissho Iwai Corporation 